\title{
Corporate Reporting of Other Comprehensive Income
}

\author{
Charles Mulford (Corresponding author) \\ Invesco Chair and Professor of Accounting, Scheller College of Business \\ Georgia Institute of Technology, 800 West Peachtree Street, NW \\ Atlanta, Georgia 30308, USA \\ E-mail: charles.mulford@ scheller.gatech.edu
}

\begin{abstract}
Anna Babinets
Graduate Research Assistant, Scheller College of Business
\end{abstract}

Georgia Institute of Technology, 800 West Peachtree Street, NW

Atlanta, Georgia 30308, USA

Received: May 8, 2018

Accepted: May 25, 2018

Published: June 13, 2018

doi:10.5296/ijafr.v8i2.13107

URL: https://doi.org/10.5296/ijafr.v8i2.13107

\begin{abstract}
In this study, we examine the annual report filings of S\&P 100 companies that report other comprehensive income/(loss) over the three-year period of 2013-2015. We seek to gain a deeper understanding of the components of other comprehensive income and to determine if there is a systematic tendency for companies to include more gains or losses in other comprehensive income. Further, we seek to determine which components of other comprehensive income show more unexpected losses than gains and what impact other comprehensive income gains and losses may have on future earnings.

We find a systematic tendency for firms to report more losses than gains in other comprehensive income, both in frequency and amount. This result is especially true for investment-related gains and losses, where managements have more discretion in the timing of gain and loss recognition.

In terms of their impact on future earnings, we find that 43 companies in the S\&P 100 reclassified some component of accumulated other comprehensive income gains and losses to
\end{abstract}


net income over the period 2013- 2015, highlighting the observation that other comprehensive income gains and losses are, in effect, future elements of net income. These results remind analysts and investors that net income does not tell the entire story of a firm's financial performance. Beyond users of financial statements, regulators, such as the FASB and SEC, may want to reconsider whether items of other comprehensive income should be included in net income.

Keywords: Other comprehensive income, OCI, Net income, Gains and losses

\section{Introduction}

Financial analysts and investors seek relevant performance measures to make effective economic resource allocation decisions. Many such readers of financial statements begin with the income statement which includes all revenues, expenses, gains, and losses recognized during the period, as well as important subtotals, such as operating income and net income. Net income provides an important focal point for evaluating corporate financial performance and often moves market prices. Since net income is carefully defined by generally accepted accounting principles (U.S. GAAP), it provides a useful measure of corporate performance that can be used for direct comparisons across firms. However, there are many gains and losses that are excluded from net income. These so-called elements of other comprehensive income (OCI) are explicitly excluded from net income by U.S. GAAP even though they consist of gains and losses that affect directly an entity's financial performance and net assets.

Consider, for example, the case of American International Group's (AIG Inc.) performance in 2015. Analysts focused on net income as the primary performance number would highlight net income of $\$ 2.2$ billion. However, that measure excludes other comprehensive loss of $\$ 8$ billion. (Note 1) Such analysis could result in favorable conclusions about AIG's corporate performance and financial results. However, if the focus were on total comprehensive loss, which includes a $\$ 6.7$ billion unrealized loss on depreciation of marketable securities and $\$ 1.1$ billion of negative foreign currency translation adjustments, the performance number would be negative, showing a comprehensive loss of $\$ 5.8$ billion. This metric would also highlight significant year-on-year volatility in total comprehensive income (2015 loss of \$5.8 billion vs. 2014 income of $\$ 11.7$ billion). This, in turn, could raise questions about AIG's performance and investment strategies, and potentially lead to a decrease in the company's market valuation.

The relevance of OCI reporting has been the topic of recent academic and industry association publications. In a CFA Institute report, Papa and Peters (2015) review bank performance reporting during the financial crisis over the period of 2006-2013 and highlight the important role of OCI in analyzing the performance of financial institutions. Based on data from 44 global banks, their report makes the case for drawing increased investor attention toward key business activities reported in the statement of other comprehensive income. Their findings show that the statement of other comprehensive income provides important economic information to users and that, for banks, losses on the statement were more common than losses on the income statement. Current academic literature also shows 
the relevance of OCI information for valuation purposes. For example, in a working paper, Doron (2011) finds that in the insurance sector, including accumulated OCI in book value multiples significantly improves the accuracy of a valuation model.

The financial media has also examined the topic of other comprehensive income. As Chasan (2014) notes, [other comprehensive income] “...has gotten a reputation as a sort of dumping ground where companies are allowed to store information that would be too damaging to earnings." The article also discusses how reporting these gains and losses in the statement of other comprehensive income, and excluding them from net income, can obscure a firm's true profit and loss picture and distort common valuation techniques used by investors. Levine (2014) takes the discussion one step further. The author highlights that companies have some choice about what accounting treatment to use for their investments and therefore may prefer to keep some investment losses "on paper" and out of net income. Both Chasan and Levine suggest that reporting losses in other comprehensive income is more attractive than recognizing those losses on the income statement because, as noted by Levine (2014), “. . . everyone agrees to treat that $[\mathrm{OCI}]$ as somewhat less important than net income".

The purpose of this paper is to review the components of other comprehensive income to gain a deeper understanding of the nature of these items, their materiality relative to net income, and whether they are primarily gains or losses. Our study builds on existing research and expands the discussion of the usefulness of OCI information beyond financial institutions. Our sample consists of the 100 firms comprising the S\&P 100. This group of firms represents a broad cross-section of major American companies from a number of industries. For this sample, we review annual financial statement filings with the Securities and Exchange Commission, including statements of comprehensive income/(loss), focusing on fiscal years 2013, 2014 and 2015. We obtain data on net income, each component of other comprehensive income, total comprehensive income, and study the relationship between these measures. We also analyze the external events that could have contributed to reporting more OCI losses and gains, as we seek to understand whether companies are attempting to engage in selective earnings management by "hiding" losses in OCI.

Our findings show that losses are more likely to be reported in other comprehensive income than on the primary income statement. We find that while in 2013 our sample companies were rather evenly split on reporting overall other comprehensive income or loss, in 2014 and 2015 over $80 \%$ of our sample companies report an overall other comprehensive loss, where other comprehensive losses exceed other comprehensive gains. These are losses that are excluded from net income. Our findings support the premise that there is a tendency for companies to report losses in OCI both more frequently and in greater amounts than gains.

The impact of different OCI components on net income varies with unrealized investment losses and negative foreign currency translation adjustments being the primary drivers of total other comprehensive losses. Our findings show that all OCI line items should be treated as precursor of future net income. In our study, 43 companies of the S\&P 100 reclassify gains and losses from accumulated OCI to the income statement over the period of 2013-2015. Derivative and investment re-measurements are transferred to earnings most frequently (89 
and 77 reclassifications, respectively). When OCI gains and losses are realized and included in net income, they often have a material impact.

Our findings indicate that analysts and investors should not overlook OCI in their analysis of corporate financial performance. By leaving material losses "on paper" and off the primary income statement, companies can paint their performance in a more positive light. Accordingly, reviewing OCI information should be part of every analyst and investor's due diligence. OCI information can enhance valuation and performance analysis by highlighting significant risk exposures and by helping readers to anticipate the impact of future reclassifications on earnings. We hope to remind all users of financial statements of the relevance and importance of other comprehensive income, and to contribute to increasing the utilization of OCI information.

\section{Background}

\subsection{Definition of Other Comprehensive Income Under U.S. GAAP}

Accounting Standards Codification 220, Reporting Comprehensive Income, defines comprehensive income as ". . . the change in equity (net assets) of a business enterprise during a period from transactions and other events and circumstances from nonowner sources," Financial Accounting Standards Board (1997). As such, comprehensive income includes all components of net income and all components of other comprehensive income. In contrast, other comprehensive income represents only those gains and losses that bypass net income on the income statement, but cause changes in stockholders' equity, except those changes in equity resulting from investments by owners and distribution to owners. Refer to Keiso, Weygandt and Warfield (2016). Thus, other comprehensive income is the difference between net income and comprehensive income.

U.S. GAAP identifies a limited number of transactions that should be recorded in other comprehensive income. The most common components of OCI consist of the following:

1. Unrealized gains and losses on available-for-sale investments,

2. Translation gains and losses on translation of foreign currency financial statements,

3. Unrealized gains and losses on derivatives held as cash flow hedges, and

4. Actuarial gains and losses arising on defined benefit pension plans.

Unrealized gains/(losses) on available-for-sale investments are holding gains/(losses) arising from changes in market prices of securities that are defined as available-for-sale. The "unrealized" part means that the gain/(loss) has yet to be settled and realized. (Note 2) Translation gains/(losses) on foreign currency financial statements typically include foreign currency gains/(losses) on intra-entity currency transactions where settlement is not planned or anticipated in the foreseeable future, as well as foreign currency translation adjustments arising from translating the financial statements of foreign subsidiaries from a foreign currency to the reporting currency. 


\section{MIN Macrothink}

International Journal of Accounting and Financial Reporting

ISSN 2162-3082

2018, Vol. 8, No. 2

With hedging-related gains/(losses) that are reported in OCI, there is a recognition mismatch. For example, a company may enter into a derivative to hedge the risk associated with some future event, (e.g., the future purchase of a commodity) that is not yet recorded in the financial statements. In order to deal with the fact that the derivative has been entered into while the future event has not yet occurred, the firm recognizes any unrealized gains/(losses) related to the derivative initially in OCI. Those gains/(losses) are then moved out of OCI and recorded in net income when the future event takes place.

Finally, pension-related gains/(losses) cover minimum pension liability adjustments on a company's pension or post-retirement benefit plans. Specifically, they may include unrealized revaluation gains/(losses) on securities held as plan assets, prior service costs or credits, and plan transition assets or obligations that are not recognized as a component of the net periodic benefit or cost in net income.

\subsection{Presentation and Disclosure of Other Comprehensive Income in Financial Statements}

Unlike items reported on the income statement, components of OCI are not closed to retained earnings each period and instead, accumulate as an element of shareholders' equity referred to as Accumulated Other Comprehensive Income (AOCI). Under U.S. GAAP, companies must report components of other comprehensive income as either (1) a single continuous statement of comprehensive income that includes the income statement, or (2) two separate but consecutive statements: an income statement and a statement of comprehensive income. Example 1 below presents an example of the reporting format for the second of two separate consecutive statements. It is obtained from the AIG, Inc. 2015 Form 10-K annual filing with the Securities and Exchange Commission (SEC).

Example 1. American International Group, Inc., Illustrative Example of the Statement of Comprehensive Income (Loss) (Two-statement approach) (in millions).

AMERICAN INTERNATIONAL GROUP, INC.

CONSOLIDATED STATEMENTS OF COMPREHENSIVE INCOME (LOSS)

\begin{tabular}{|c|c|c|c|c|c|c|}
\hline \multirow[b]{2}{*}{ (in millions) } & \multicolumn{6}{|c|}{ Years Ended December 31, } \\
\hline & \multicolumn{3}{|c|}{2015} & \multicolumn{2}{|c|}{2014} & \multirow{2}{*}{$\begin{array}{r}2013 \\
9,092 \\
\end{array}$} \\
\hline Net income & $\$$ & 2,222 & $\$$ & 7,524 & $\$$ & \\
\hline \multicolumn{7}{|l|}{ Other comprehensive income (loss), net of tax } \\
\hline Change in unrealized appreciation (depreciation) of fixed maturity securities on & & & & & & \\
\hline which other-than-temporary credit impairments were recognized & & (347) & & 107 & & 361 \\
\hline Change in unrealized appreciation (depreciation) of all other investments & & $(6,762)$ & & 5,538 & & $(6,673)$ \\
\hline Change in foreign currency translation adjustments & & $(1,100)$ & & $(832)$ & & (556) \\
\hline Change in net derivative gains arising from cash flow hedging activities & & - & & - & & - \\
\hline Change in retirement plan liabilities adjustment & & 123 & & $(556)$ & & 631 \\
\hline Other comprehensive income (loss) & & $(8,086)$ & & 4,257 & & $(6,237)$ \\
\hline Comprehensive income (loss) & & $(5,864)$ & & 11,781 & & 2,855 \\
\hline $\begin{array}{l}\text { Comprehensive income (loss) attributable to noncontrolling nonvoting, callable, } \\
\text { junior and senior preferred interests }\end{array}$ & & - & & - & & - \\
\hline Comprehensive income (loss) attributable to other noncontrolling interests & & 20 & & (5) & & (16) \\
\hline Total comprehensive income (loss) attributable to noncontrolling interests & & 20 & & (5) & & $(16)$ \\
\hline Comprehensive income (loss) attributable to AIG & $\mathbf{s}$ & $(5,884)$ & $\$$ & 11,786 & $\$$ & 2,871 \\
\hline
\end{tabular}

Source: AIG, Inc. Form 10-K Annual Report to the SEC, December 31, 2015. 
As seen in Example 1, the Statement of Comprehensive Income (Loss) is effectively a reconciliation of net income to comprehensive income, where elements of other comprehensive income are highlighted. Note that in 2015 , the company incurred $\$ 8.1$ billion in other comprehensive losses. There is no mention of the $\$ 8.1$ billion in other comprehensive losses on AIG's income statement. While the equity section of the balance sheet shows total AOCI as a single line item, it does not provide detail on what caused the loss, or how economic events affected the fair value of the company's assets and its foreign currency position at the end of the reporting period. These details are reported in a statement of comprehensive income, e.g., Example 1, that is separate from the balance sheet and income statement.

Although GAAP requires prominent display of other comprehensive income and comprehensive income, the focus for performance analysis remains on the income statement, where analysts direct their attention to operating income, net income and EPS. Operating income, net income and EPS exclude elements of other comprehensive income, which nonetheless, can affect a firm's financial well-being.

\subsection{Flexibility in Reporting Other Comprehensive Income}

In other comprehensive income, one would expect that gains and losses would be somewhat equal and offsetting. However, that said, firm managements are offered considerable leeway in deciding what elements of gain or loss are included in net income or in other comprehensive income.

Consider, for example, investments classified as available-for-sale. Unrealized gains and losses on these investments are excluded from net income and reported in other comprehensive income. Realized gains and losses are reported in net income. A firm may delay the recognition in net income of an investment-related loss by not selling the investment but by holding it, allowing the loss to accumulate in other comprehensive income. Consider too a defined-benefit pension plan. Here a firm may elect a fair-value approach and flow actuarial gains and losses and any gains or losses related to plan amendments through net income. In the absence of such an election, these gains and losses are included in other comprehensive income and not reported in net income, permitting a firm to delay the recognition in net income of pension-related losses. For investments in foreign entities translated under the all-current method, translation-related gains and losses are reported in other comprehensive income. When these investments are liquidated, either in whole or in part, any gain or loss related to the liquidated portion is reported in net income. Here again, by not selling the investment, currency-related losses may be excluded from net income. When certain criteria are met, firms may elect and apply hedge accounting and report hedge-related gains and losses on cash flow hedges in other comprehensive income, excluding them from net income. (Note 3) When hedge accounting is not applied, these same hedge-related gains and losses would flow through net income.

Given the leeway that managers are afforded in deciding what elements of gain or loss are included in net income or in other comprehensive income, it is possible that they are managing the timing of the recognition of gains and losses in net income. That is, we may observe that losses are more frequently reported in other comprehensive income while gains 


\section{Mll Macrothink}

International Journal of Accounting and Financial Reporting

ISSN 2162-3082

2018, Vol. 8, No. 2

are directed toward net income. If so, it would imply that net income is reported artificially at a higher level than would be obtained if all other comprehensive income gains and losses were recorded in net income as they occurred.

\subsection{Other Comprehensive Income Is Future Net Income}

Accumulated other comprehensive income includes accumulated gains and losses that have yet to be recognized in net income. AOCI usually appears as a separate line item on the statement of shareholder's equity. If an item listed in other comprehensive income becomes a realized gain or loss, it shifts from AOCI to the income statement. This is commonly referred to as reclassification or "recycling." This can happen, for example, when a company sells an investment security for which it already recorded an unrealized gain in other comprehensive income. At the point of sale, this becomes a realized gain and therefore moves from AOCI into net income. According to ASC 220 (FASB 1997), companies are required to display the effects of significant amounts reclassified out of AOCI on the respective line items in net income or to cross-reference to other disclosures that provide additional details on these reclassifications. Companies may decide whether to show components of comprehensive income on a gross basis or net of reclassification adjustments.

Hence, while the exclusion from net income of OCI losses can increase net income in the current reporting period, it does not mean the company will not record these losses in a future year. The opposite is also true. Consider the following example of one S\&P100 company from our sample. During the reporting period ended July 25, 2015, Cisco Systems, Inc. reported $\$ 157$ million of realized gains on available-for-sale investments which the company added to net income following the sale of the investments. During the same period the company also incurred a $\$ 154$ million loss from reclassification of foreign currency derivatives. Example 2 below illustrates both reclassifications and shows that OCI items can be expected to eventually flow through net income, often leading to a material impact on earnings.

Example 2. Cisco Systems, Inc., Illustrative Disclosure on Net Gains (Losses) Reclassified out of Accumulated Other Comprehensive Income and into Net Income (in millions).

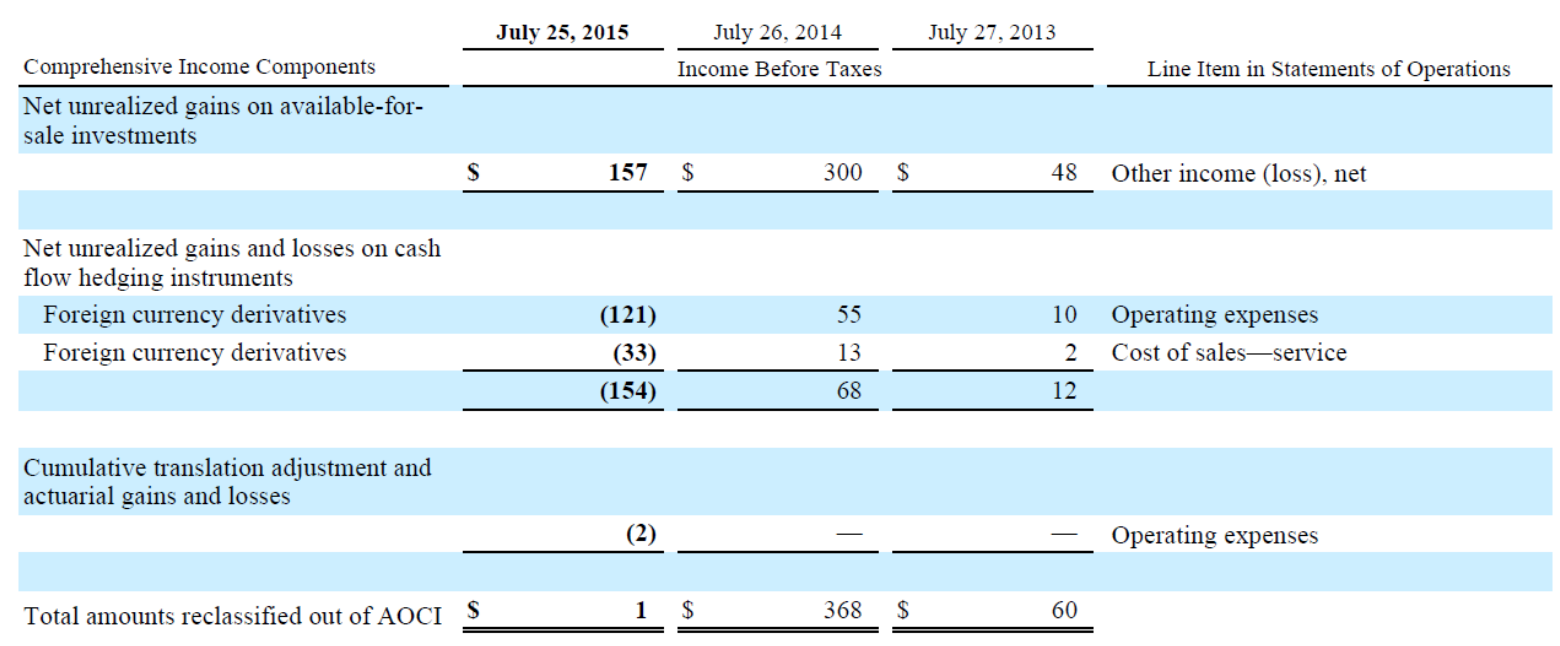

Source: Cisco Systems, Inc. Form 10-K Annual Report to the SEC, July 25, 2015. 


\section{Macrothink \\ International Journal of Accounting and Financial Reporting \\ ISSN 2162-3082 \\ 2018, Vol. 8, No. 2}

\section{Design}

The purpose of this paper is to review the components of other comprehensive income to gain a deeper understanding of the nature of these items, their materiality relative to net income, and whether they are primarily gains or losses. Our sample consists of the 100 companies comprising the S\&P 100. This group of firms represents a broad cross-section of major American companies from a diverse range of industries. For this sample, we review each firm's annual report for the years 2013, 2014, and 2015, including their income statements, statements of comprehensive income, and accompanying notes explaining any reclassifications out of AOCI into the net income. We identify each gain and loss reported within other comprehensive income to determine if gains or losses are reported in OCI more frequently. We also prepare a reconciliation between net income/(loss) and total comprehensive income/(loss) in percentages of net income/(loss) in order to understand the potential impact of future OCI reclassifications on earnings.

\section{Results}

We prepare a reconciliation in percentage terms of net income to total comprehensive income, where net income represents $100 \%$, for each company from our sample for fiscal years 2013-2015. The data are obtained from the statements of other comprehensive income and, where applicable, the combined statements of operations and comprehensive income. All gains/(losses) reported in OCI are classified into 5 general categories. These five categories consist of the four primary components of other comprehensive income discussed earlier, namely, available-for-sale investment gains/(losses), foreign currency gains/(losses), derivatives-related gains/(losses) and pension gains/(losses), as well as a category labelled as other gains/(losses). This other category includes such items as the share of other comprehensive income/(loss) attributable to noncontrolling interests, the change in the deferred tax asset valuation allowance (Intel Corporation), OCI related to equity method investees (NextEra Energy Inc., and Exelon Corporation), dividends on preferred and preference stock of subsidiaries (Southern Company), and other gains/(losses). (Note 4)

Under U.S. GAAP it is acceptable to either report components of other comprehensive income net of related tax effects, or before related tax effects with a single aggregate income tax expense (benefit) shown that relates to all OCI items. For nine companies in our sample, OCI items are reported on a gross basis and related income tax expense (benefit) is reported as a single aggregate line item. For consistency, we allocate this tax charge (benefit) on a relative basis to each component of OCI, assuming the same tax rate applies to all OCI components.

\subsection{Prevalence of Losses in Other Comprehensive Income}

In comparing comprehensive income with net income, we observe a prevalence of OCI losses with a high variability in amounts. Table 1 below presents the percent of sample firms that report other comprehensive income and other comprehensive loss along with the average amounts of each reported as a percentage of net income. 


\section{MIN Macrothink}

International Journal of Accounting and Financial Reporting

ISSN 2162-3082

2018, Vol. 8, No. 2

Tables 2 and 3 detail the components of OCI that contributed the most to the net comprehensive income/(loss). We use the results in Tables 2 and 3 to identify patterns in OCI and to determine if any category of OCI gains/(losses) would stand out as being more likely to result in losses.

In calculating the average gains and losses presented in Tables 2 and 3, we use judgment to exclude significant outliers. Several gains and losses are quite distant from the mean and some categories of OCI line items show great variability in amounts. Overall, we exclude 13 items of investment gains/(losses), 12 items of pension-related gains/(losses), 8 items of foreign currency gains/(losses), and 8 items of derivative gains/(losses). Exhibit 1 in the Appendix provides detailed information on all excluded outliers. This design decision allows for a more meaningful comparison between different periods and categories and more realistic averages.

Table 1. Percent of sample companies reporting other comprehensive income and other comprehensive loss, with the mean and median amounts reported as a percentage of net income

\begin{tabular}{crrr}
\hline & $2015^{\mathrm{a}}$ & $2014^{\mathrm{b}}$ & $2^{2013^{\mathrm{c}}}$ \\
\hline Companies that report Other Comprehensive Income, \% & $15 \%$ & $19 \%$ & $54 \%$ \\
\hline Mean Other Comprehensive Income, \% of Net Income & $12.92 \%$ & $29.83 \%$ & $39.82 \%$ \\
\hline Median Other Comprehensive Income, \% of Net Income & $3.94 \%$ & $9.25 \%$ & $16.36 \%$ \\
\hline Companies that report Other Comprehensive Loss, \% & $85 \%$ & $81 \%$ & $46 \%$ \\
\hline Mean Other Comprehensive Loss, \% of Net Income & $-25.24 \%$ & $-34.91 \%$ & $-15.64 \%$ \\
\hline Median Other Comprehensive Loss, \% of Net Income & $-11.94 \%$ & $-17.85 \%$ & $-6.81 \%$ \\
\hline
\end{tabular}

${ }^{\mathrm{a}}$ Mean other comprehensive loss is $-12.32 \%$ and is less than zero at the .05 level.

${ }^{\mathrm{b}}$ Mean other comprehensive loss is $-21.54 \%$ and is less than zero at the .05 level.

${ }^{c}$ Mean other comprehensive income is $4.76 \%$ and is greater than zero at the .05 level.

Table 2. Average (mean) gains as a percentage of net income for companies that report total other comprehensive income

\begin{tabular}{rrrrrrr}
\hline & $\begin{array}{c}\text { Foreign } \\
\text { currency } \\
\text { gain/(loss) }\end{array}$ & $\begin{array}{c}\text { Pension } \\
\text { gain/(loss) }\end{array}$ & $\begin{array}{r}\text { Investment } \\
\text { gain/(loss) }\end{array}$ & $\begin{array}{c}\text { Derivatives } \\
\text { gain/(loss) }\end{array}$ & $\begin{array}{c}\text { Debt } \\
\text { valuation } \\
\text { gain/(loss) }\end{array}$ & Other \\
\hline 2015 & $0.74 \%$ & $7.10 \%$ & $1.39 \%$ & $1.54 \%$ & $3.87 \%$ & $1.51 \%$ \\
\hline 2014 & $9.33 \%$ & $3.35 \%$ & $2.71 \%$ & $3.96 \%$ & - & $1.12 \%$ \\
\hline 2013 & $2.20 \%$ & $19.14 \%$ & $2.09 \%$ & $1.48 \%$ & & $26.32 \%$ \\
\hline
\end{tabular}




\section{Mll Macrothink}

International Journal of Accounting and Financial Reporting

ISSN 2162-3082

2018, Vol. 8, No. 2

Table 3. Average (Mean) Losses as a Percentage of Net Income for Companies that Report Total Other Comprehensive Loss

\begin{tabular}{lcccccc}
\hline & $\begin{array}{c}\text { Foreign } \\
\text { currency } \\
\text { gain/(loss) }\end{array}$ & $\begin{array}{c}\text { Pension } \\
\text { gain/(loss) }\end{array}$ & $\begin{array}{c}\text { Investment } \\
\text { gain/(loss) }\end{array}$ & $\begin{array}{c}\text { Derivatives } \\
\text { gain/(loss) }\end{array}$ & $\begin{array}{c}\text { Debt } \\
\text { valuation } \\
\text { gain/(loss) }\end{array}$ & Other \\
\hline 2015 & $-17.08 \%$ & $-3.70 \%$ & $-3.80 \%$ & $-1.62 \%$ & - & $-1.82 \%$ \\
\hline 2014 & $-17.24 \%$ & $-13.61 \%$ & $-1.63 \%$ & $-2.45 \%$ & - & $-3.73 \%$ \\
\hline 2013 & $-6.51 \%$ & $-2.24 \%$ & $-9.67 \%$ & $-2.33 \%$ & - & $-3.23 \%$ \\
\hline
\end{tabular}

Our findings show a prevalence of losses in other comprehensive income. Specifically, in $201585 \%$ of companies report other comprehensive loss compared to $15 \%$ reporting other comprehensive income. In 2014, $81 \%$ of companies report other comprehensive loss, while in 2013, the number of companies reporting losses and gains are approximately equal, with 54\% reporting other comprehensive gains. Refer to Table 1. In comparing the mean and median amounts of gains and losses reported, we see that the mean and median other comprehensive loss exceeds other comprehensive income in two of the three years studied, 2015 and 2014. In 2015, sample companies report mean other comprehensive loss of $-12.32 \%$, which is significantly less than zero at the .05 level. In 2014, sample companies report mean other comprehensive loss of $-21.54 \%$, which is significantly less than zero at the .05 level. Mean and median gains exceed losses in 2013. In 2013, sample companies report mean other comprehensive income of $4.76 \%$, which is significantly greater than zero at the .05 level. Overall, our data suggest a tendency for companies to keep losses in OCI both more frequently and in larger amounts than gains.

In examining Tables 2 and 3, where gains and losses are presented as a percentage of net income, we see that other comprehensive losses are driven mostly by negative foreign currency translation adjustments and unrealized losses on available-for-sale investments. The prevalence of other comprehensive losses driven by negative foreign currency translation adjustments is understandable given the general strength of the dollar over the 2013 through 2015 time period. As the dollar appreciates, companies experience losses on subsidiaries and associate companies denominated in foreign currencies. However, it is interesting that the average (mean) amount of unrealized investment gains is less than average amount of unrealized investment losses for two of the three years studied. This result obtained even in a period of generally upward stock and bond price movements. For example, as observed in Tables 2 and 3, in 2013 unrealized losses on available-for-sale investments as a percentage of net income is $9.67 \%$ compared to investment gains of $2.09 \%$. The average amount of losses on investments also exceeds gains in 2015. In 2014, average investment gains exceed losses only marginally. These results suggest that companies may be delaying recognition of investment losses by keeping more losses than gains in other comprehensive income. 


\section{Ml Macrothink}

International Journal of Accounting and Financial Reporting

ISSN 2162-3082

Given the prevalence of losses in OCI, the expectation is that we may be seeing in OCI, losses that will impact future net income. A few companies stand out for the largest losses reported in OCI, including AIG Inc., and MetLife, Inc.

We see that while the income statement accurately reflects a firm's past profitability, it has some shortcomings and could be open to manipulation. Our findings show that companies may try to leverage OCI as an accepted way of reporting more gains in the income statement, while keeping losses in OCI. Since companies have a fair amount of freedom on the timing and impact of losses, they may delay recognition of losses until the actual financial situation improves to positively influence investor perceptions of their performance. A careful review of both the income statement and statement of comprehensive income will allow analysts and investors to account for this "cherry picking" tendency. By shifting the analysis focus from net income to comprehensive income, users can get better insights into the total wealth created for shareholders and anticipate how OCI gains/(losses) would impact future earnings.

\subsection{Results Specific to Each Component of Other Comprehensive Income}

We review each component of OCI to better understand what category may allow for easier manipulation of earnings. Tables 4-8 below present summary statistics for each of these four main categories of other comprehensive income. In reviewing the results, we seek to understand whether the recorded OCI gains and losses align with our expectations and external economic factors or, if not, whether there is evidence to suggest that management may be selectively choosing to keep more losses than gains in OCI. Also, we review the largest reclassifications from AOCI to the income statement for each category to see what impact they could have on future earnings.

\subsubsection{Investment Gains and Losses}

Recall that investment gains/(losses) recognized in other comprehensive income include re-measurements to fair value of available-for-sale securities. Table 4 below presents the distribution and mean of Investment gains/(losses) reported in OCI by our sample companies over the three-year period. Assuming most of these gains/(losses) come from investments in equity securities, one may expect that an increase in stock prices, as measured by the major indices, would result in seeing more investment gains in OCI. The opposite would also be true, with stock price declines leading to the prevalence of investment losses.

Table 5 below presents the annual changes in mean investment gains/(losses) for all 100 companies from our sample along with the changes in major stock market indices (S\&P500, NASDAQ, Dow Jones Industrial Average, and NYSE Composite Index) over the same time periods. 


\section{1) Macrothink}

International Journal of Accounting and Financial Reporting

Table 4. Distribution and mean for investment gains and losses reported in OCI

\begin{tabular}{lccc}
\hline & $\begin{array}{c}\text { Number of } \\
\text { companies }^{\mathrm{a}}\end{array}$ & $\begin{array}{c}\text { \% of companies } \\
\text { with gains or losses }\end{array}$ & $\begin{array}{c}\text { Main/(loss), as \% of } \\
\text { Net Income }^{\mathrm{b}}\end{array}$ \\
\hline $\mathbf{2 0 1 3}$ & 30 & & \\
Investment gain & 44 & $41 \%$ & $2.09 \%$ \\
Investment loss & & $59 \%$ & $-9.67 \%$ \\
\hline $\mathbf{2 0 1 4}$ & 45 & $63 \%$ & $2.71 \%$ \\
Investment gain & 27 & $37 \%$ & $-1.63 \%$ \\
Investment loss & & & \\
\hline $\mathbf{2 0 1 5}$ & 19 & $25 \%$ & $1.39 \%$ \\
Investment gain & 57 & $75 \%$ & $-3.80 \%$ \\
Investment loss & & & \\
\hline
\end{tabular}

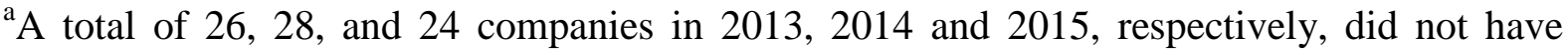
Investment gains (losses) in Other Comprehensive Income.

${ }^{\mathrm{b}}$ Mean is calculated excluding outliers listed in Exhibit 1.

Table 5. Mean Investment Gains (Losses) vs. Changes in Stock Market Indices

\begin{tabular}{rrrrrr}
\hline & All 100 firms & \multicolumn{5}{c}{ Annual change in major stock market indices } \\
\cline { 2 - 7 } Year & $\begin{array}{c}\text { Mean investment } \\
\text { gain/(loss), \% of } \\
\text { Net Income }\end{array}$ & S\&P500 & NASDAQ & $\begin{array}{c}\text { Dow Jones } \\
\text { Industrial Average }\end{array}$ & $\begin{array}{c}\text { NYSE Composite } \\
\text { Index }\end{array}$ \\
\hline 2013 & $-3.63 \%^{\mathrm{b}}$ & $30 \%$ & $38 \%$ & $26 \%$ & $23 \%$ \\
\hline 2014 & $0.66 \%^{\mathrm{c}}$ & $11 \%$ & $13 \%$ & $8 \%$ & $-6 \%$ \\
\hline 2015 & $-1.28 \%^{\mathrm{d}}$ & $-1 \%$ & $6 \%$ & $-2 \%$ & $-6 \%$ \\
\hline
\end{tabular}

${ }^{\mathrm{a}}$ Excluding dividends.

${ }^{\mathrm{b}}$ Significantly less than zero at the .05 level.

${ }^{\mathrm{c}}$ Significantly greater than zero at the .05 level.

${ }^{\mathrm{d}}$ Significantly less than zero at the .05 level.

In reviewing Table 4, we see that in 2013 and 2015, 59\% and 75\%, respectively, of our sample companies choose to leave investment losses in OCI and exclude them from the income statement. For these years, the amount of mean investment losses exceeds the amount of mean investment gains. In both years, 2013 and 2015, sample-wide mean investment losses included in OCI are significantly less than zero at the .05 level. While our data do not speak to the motives of the decisions made to recognize losses in OCI, it can indicate a 
general tendency to delay the recognition of losses. By keeping investment losses "on paper" and off the income statement, companies are able to paint their performance in a more positive light. In 2014, sample-wide mean investment gains are significantly greater than zero at the .05 level.

Table 5 suggests that investment results reported in OCI tend to underperform results obtained by general stock market indices. For example, in 2013, while the mean investment loss included in OCI, as a percent of net income is $-3.63 \%$, major U.S. stock indices were reporting gains of between $23 \%$ and $38 \%$. In 2014, the mean investment gains included in OCI, as a percent of net income is $.66 \%$, in a year when major U.S stock indices were reporting gains of between $4 \%$ and $13 \%$. In 2015, mean investment losses included in OCI as a percent of net income is $-1.28 \%$, which was reflective of a general down year for stocks generally, as the S\&P 500 declined one percent that year.

We observe multiple reclassifications of investment gains and losses from AOCI to the income statement. In fiscal years 2013-2015, 77 such reclassifications occurred for 27 companies in the S\&P100. The total value of reclassifications varied greatly from $\$ 796$ million of investment loss (Pfizer Inc.) to $\$ 3,360$ million of investment gain (Berkshire Hathaway Inc.) - both were reclassified from AOCI to net income following the sale of the underlying securities. These reclassifications show that unrealized gains and losses may indeed have a material effect on future earnings.

Our findings affirm that companies may delay recognition of investment losses by keeping them in other comprehensive income. An easy way to achieve this result is by postponing the sale of available-for-sale securities for which losses are recorded in OCI. Since other comprehensive income is often treated as somewhat less important than net income, OCI losses are less prominent and less likely to catch investors' attention. The abundance of reclassifications from OCI to net income demonstrates that ignoring unrealized losses can affect financial analysis. Hence, it is important for readers of financial statements to pay attention to these OCI line items. Taking a closer look at OCI could provide analysts with better insights on how companies manage their investments and whether potential future losses should be anticipated.

\subsubsection{Foreign Currency Gains and Losses}

Foreign currency translation gains/(losses) recognized in OCI include the effects of translating the financial statements of foreign subsidiaries and associate companies to the presentation currency and the effects of certain foreign currency transactions. All S\&P100 companies use the U.S. dollar as their presentation currency in their $10-\mathrm{K}$ filings. Since the value of the U.S. dollar increased during the study period, the expectation is that multinational companies would record more foreign currency losses than gains in OCI. (Note 5) Table 6 below presents the distribution and summary statistics for foreign currency gains and losses reported in OCI. 


\section{MInstitute ${ }^{\text {Mink }}$}

International Journal of Accounting and Financial Reporting

ISSN 2162-3082

Table 6. Distribution and mean for foreign currency gains and losses reported in OCI

\begin{tabular}{lccc}
\hline & $\begin{array}{c}\text { Number of } \\
\text { companies }^{\mathrm{a}}\end{array}$ & $\begin{array}{c}\text { \% of } \\
\text { companies }\end{array}$ & $\begin{array}{c}\text { Mean foreign currency } \\
\text { gain/(loss), \% of Net } \\
\text { Income }\end{array}$ \\
\hline $\mathbf{2 0 1 3}^{\text {c }}$ & & & \\
Foreign currency gain & 28 & $29 \%$ & $2.20 \%$ \\
Foreign currency loss & 67 & $71 \%$ & $-6.51 \%$ \\
\hline $\mathbf{2 0 1 4}^{\text {d }}$ & & & \\
Foreign currency gain & 7 & $7 \%$ & $9.33 \%$ \\
Foreign currency loss & 90 & $93 \%$ & $-17.24 \%$ \\
\hline $\mathbf{2 0 1 5}^{\text {e }}$ & & & \\
Foreign currency gain & 8 & $8 \%$ & $-17.08 \%$ \\
\hline Foreign currency loss & 88 & $92 \%$ & $-74 \%$ \\
\hline
\end{tabular}

a 5,3 , and 4 companies, respectively, did not have Foreign currency gains (losses) in Other Comprehensive Income in 2013, 2014 and 2015.

${ }^{\mathrm{b}}$ Mean is calculated excluding outliers listed in Exhibit 1.

${ }^{c}$ Sample-wide mean foreign currency losses included in OCI as a percent of net income are $-3.78 \%$ and is significantly less than zero at the .05 level.

d Sample-wide mean foreign currency losses included in OCI as a percent of net income are $-13.46 \%$ and is significantly less than zero at the .05 level.

${ }^{\mathrm{e}}$ Sample-wide mean foreign currency losses included in OCI as a percent of net income are $-14.19 \%$ and is significantly less than zero at the .05 level.

As expected, we see that during the years 2013 through 2015, most sample companies (depending on the year, between $71 \%$ and $93 \%$ ), report foreign currency losses in OCI as opposed to foreign currency gains. The amount of mean foreign currency losses exceeds the amount of mean foreign currency gains in each reporting period. Across the entire sample, mean foreign currency losses reported in OCI as a percentage of net income are $-14.19 \%$, $-13.46 \%$ and $-3.78 \%$, respectively, in 2015, 2014 and 2013, and are significantly less than zero at the .05 level in all three years.

Thus, our sample companies report foreign currency losses in OCI both more frequently and in larger amounts than gains. The observed trend is in line with the recent appreciation of the U.S. dollar, as measured by the U.S. Dollar index (DXY). The DXY Index is a measure of the value of the U.S. dollar relative to the value of a basket of currencies of U.S.'s most significant trading partners. The index improved by $0.36 \%, 12.74 \%$, and $8.29 \%$ during 2013 , 2014, and 2015, respectively. (Note 6)

Given the strengthening of U.S. dollar, the prevalence of foreign currency losses should be mostly attributed to the external factors that are outside of a company's control (i.e. volatility 
in exchange rates) as opposed to internal factors (i.e. managers' preference to keep losses in OCI). When we look at reclassifications of foreign currency gains/(losses) from AOCI to net income, we see that most of them are also driven by external events. For example, Mondelez International Inc. reclassified $\$ 99$ million of realized exchange losses following the deconsolidation of its Venezuela subsidiary in 2015. The recorded loss includes historical cumulative translation adjustments related to Venezuelan operations which had previously been recorded within equity. This deconsolidation decision was driven by external events as the Venezuelan legal and regulatory environment became unreliable. PepsiCo Inc. provides a similar example of deconsolidation. In 2015, the company recorded a $\$ 111$ million loss (2\% net income) from the reclassification of cumulative translation losses on previously consolidated Venezuelan subsidiaries and joint ventures.

These companies are not the only ones affected by reclassification of foreign exchange gains and losses. Overall, 32 reclassifications of foreign currency gains/(losses) are recorded by 12 companies in the sample. The value of reclassifications varied from $\$ 416$ million of foreign currency loss (AT\&T) to $\$ 62$ million in foreign currency gains (Pfizer Inc.). Losses are reclassified more often than gains by a factor of three to one.

While one could argue that translation effects are "non-operating" gains (losses) and so are less relevant, we see that OCI can provide useful insights on how well a company manages its foreign currency risks, and it can also point out potential problems before these losses flow through the income statement. We believe that since translation gains/(losses) affect shareholder value, they are important to determining real value creation for the shareholder. Significant unrealized foreign currency losses can highlight the need for additional planning to minimize the impact of future reclassifications on earnings. Hence, OCI scrutiny is vital to avoiding unexpected surprises.

\subsubsection{Pension-Related Gains and Losses}

Pension-related re-measurements included in OCI include unrealized revaluation gains/(losses) on securities held as plan assets, prior service costs or credits, as well as plan transition assets or obligations that are not recognized as a component of net periodic benefit/cost in net income. Since the movement in pension remeasurements depends on a combination of external factors and firms' internal activities, it is not clear what would be the net effect on OCI. With a recent run of stock market gains, we expect the actual return on equity investments held as plan assets to exceed expected returns, resulting in OCI gains. (Note 7) At the same time U.S. interest rates were at their historical lowest level of 0.25-0.50\% during 2013-2015 and it would have a dual effect on OCI (Note 8). On one hand, lower interest rates increase the present value of pension obligations, leading to actuarial losses. On the other hand, lower interest rates increase the value of debt securities held as plan assets, leading to actuarial gains. Other miscellaneous events such as plan changes, higher or lower settlement activity and changes in mortality assumptions would be specific to each company, and we expect the effect of these events to be immaterial. Table 7 below presents the distribution and summary statistics for pension gains/(losses) reported in OCI by the S\&P100 companies over 2013-2015. 


\section{MInstitute ${ }^{\text {Mink }}$}

International Journal of Accounting and Financial Reporting

Table 7. Distribution and mean for pension gains and losses reported in OCI

\begin{tabular}{lrrr}
\hline & $\begin{array}{c}\text { Number of } \\
\text { companies }^{\mathrm{a}}\end{array}$ & $\begin{array}{c}\text { \% of } \\
\text { companies }\end{array}$ & $\begin{array}{c}\text { Mean pension } \\
\text { gain/(loss), \% of } \\
\text { Net Income }^{\mathrm{b}}\end{array}$ \\
\hline $\mathbf{2 0 1 3}^{\text {c }}$ & 74 & $93 \%$ & $19.14 \%$ \\
Pension gain & 6 & $8 \%$ & $-2.24 \%$ \\
Pension loss & & & \\
\hline $\mathbf{2 0 1 4}^{\text {d }}$ & 7 & $9 \%$ & $3.35 \%$ \\
Pension gain & 74 & $91 \%$ & $-13.61 \%$ \\
Pension loss & & & \\
\hline $\mathbf{2 0 1 5}^{\text {e }}$ & 52 & $66 \%$ & $7.10 \%$ \\
Pension gain & 27 & $34 \%$ & $-3.70 \%$ \\
Pension loss & & & \\
\hline
\end{tabular}

a20, 19, and 21 companies, respectively, did not have Pension gains (losses) in Other Comprehensive Income in 2013, 2014 and 2015.

${ }^{\mathrm{b}}$ Mean was calculated excluding outliers listed in Exhibit 1.

${ }^{\mathrm{c}}$ Sample-wide mean pension gains included in OCI as a percent of net income are $13.82 \%$ and is significantly greater than zero at the .05 level.

${ }^{\mathrm{d}}$ Sample-wide mean pension losses included in OCI as a percent of net income are $9.60 \%$ and is significantly less than zero at the .05 level.

${ }^{\mathrm{e}}$ Sample-wide mean pension gains included in OCI as a percent of net income are $2.83 \%$ and is significantly greater than zero at the .05 level.

From Table 7, we see significant volatility in the amounts of pension gains and losses reported in OCI and no clear prevalence of losses. In fact, more companies report pension-related gains than losses in 2013 and 2015, while the opposite is true for 2014. We see that pension remeasurements can be material: unrealized pension losses comprise $13.61 \%$ of net income in 2014, and unrealized pension gains represent $19.14 \%$ of net income in 2013. Recall that such re-measurements bypass the income statement due to the high volatility in the fair value of pension plan assets and liabilities. The data above illustrate this point. By excluding these items from net income, a much less volatile measure of net income is afforded.

Initially we assumed that any effect of pension-related reclassifications on net income would be long-term, so we did not expect to see many reclassifications. However, the observed results are on par with reclassifications of foreign currency gains/(losses). Specifically, 36 items of pension-related gains/(losses) are reclassified from AOCI by 12 S\&P100 companies during 2013-2015. The total value of reclassifications varied from $\$ 1,029$ million of pension losses (Pfizer Inc.) to $\$ 78$ million of pension gains (PepsiCo Inc). Common reasons for 
reclassifications include amortization of losses, amortization of prior service benefits and costs, plan settlement or curtailment (DuPont, Mondelez International Inc.), and plan adjustments related to subsidiary deconsolidation (Mondelez International Inc). Some reclassifications have a material impact on earnings. For example, Lockheed Martin Corporation reclassified $\$ 1,015$ million, $\$ 706$ million and $\$ 850$ million of pension-related losses from AOCI to the income statement, which comprises $34 \%, 20 \%$ and $23 \%$ of company's net earnings in 2013, 2014 and 2015, respectively. Similarly, Pfizer Inc. reclassified the net amount of $\$ 1,029$ million or $15 \%$ of total net income in 2015 .

Based on the above, one cannot say with certainty what would be the net effect from pension-related reclassifications on future earnings given how "noisy" these items are. However, we see that the impact of such reclassifications can be material, so it is important to take pension gains/(losses) seriously when they appear in other comprehensive income. The CFA Institute report referenced earlier, see Papa and Peters (2015), underscores this point. The report quotes IASB Chairman Hans Hoogervorst (2014), who noted,

Unrealized income does not only consist of gains, but also of losses. Downplaying the significance of unrealized losses can be very hazardous.

A very real example of the dangers of relegating unrealized losses to OCI is what happened in the first decade of this century with some big American car manufacturers and airline companies. Their employee benefit schemes had caused huge liabilities to build accumulated OCI. Although unrealized, these deficits were not unreal.

While income in OCI may be of a less certain nature than income captured in profit or loss, OCI may contain indicators of risk that may materialize sooner than you think. Clearly, ignoring unrealized elements of income may be hazardous to your financial health.

Thus, both the speech, CFA report and our study emphasize that all OCI items, including pension remeasurements, have important economic information content and should not be ignored. Since pension-related gains/(losses) are accumulated in equity over many years, these OCI items are likely to lead to material reclassifications in the future. If readers of financial statements do not pay attention to OCI, they can be blindsided by the ultimate income statement effects of these reclassifications.

\subsubsection{Derivative Gains and Losses}

The last category of primary OCI items includes unrealized gains/(losses) on derivatives held as cash flow hedges. These derivative instruments hedge the exposure to variability in cash flows of a recognized asset/liability or cash flows from an anticipated transaction. They can be used, for example, to hedge variable interest rates, foreign currency exposure, or commodity price risks. Table 8 below presents distribution and summary statistics for derivative gains and losses reported in OCI by the S\&P100 companies. 


\section{Macrothink}

International Journal of Accounting and Financial Reporting

Table 8. Distribution and mean for derivative gains and losses reported in OCI

\begin{tabular}{lcrr}
\hline & $\begin{array}{c}\text { Number of } \\
\text { companies }^{\mathrm{a}}\end{array}$ & $\begin{array}{c}\text { \% of } \\
\text { companies }\end{array}$ & $\begin{array}{c}\text { Mean derivative } \\
\text { gain/(loss), \% of Net } \\
\text { Income }^{\mathrm{b}}\end{array}$ \\
\hline $\mathbf{2 0 1 3}^{\mathrm{c}}$ & 39 & $51 \%$ & $1.48 \%$ \\
$\begin{array}{l}\text { Derivative gain } \\
\text { Derivative loss }\end{array}$ & 37 & $49 \%$ & $-2.33 \%$ \\
\hline $\mathbf{2 0 1 4}^{\text {d }}$ & & & \\
Derivative gain & 48 & $66 \%$ & $3.96 \%$ \\
Derivative loss & 25 & $34 \%$ & $-2.45 \%$ \\
\hline $\mathbf{2 0 1 5}^{\text {e }}$ & & & \\
Derivative gain & 33 & $45 \%$ & $-1.54 \%$ \\
Derivative loss & 41 & $55 \%$ & \\
\hline
\end{tabular}

a 24, 27, and 26 companies, respectively, did not have Derivative gains (losses) in Other Comprehensive Income in 2013, 2014 or 2015.

${ }^{\mathrm{b}}$ Mean was calculated excluding outliers listed in Exhibit 1.

${ }^{c}$ Sample-wide mean derivative losses included in OCI as a percent of net income are $.30 \%$ and are not significantly less than zero at the .05 level.

${ }^{\mathrm{d}}$ Sample-wide mean derivative gains included in OCI as a percent of net income are $1.21 \%$ and are significantly greater than zero at the .05 level.

${ }^{\mathrm{e}}$ Sample-wide mean derivative losses included in OCI as a percent of net income are $.13 \%$ and are not significantly less than zero at the .05 level.

After excluding significant outliers (Refer to the Appendix, Exhibit 1), we see that over the 2013 to 2015 time period, mean unrealized derivative gains and losses represent between one and four percent of net income. The mean values are low because derivative gains and losses are distributed approximately equally and therefore offset each other. If we look at the derivative gains/(losses) reclassified from AOCI to the income statement, we see that this category has the greatest number of reclassifications. In fiscal years 2013-2015, 89 reclassifications are reported by 30 companies from our sample. The total value of reclassifications varied from $\$ 477$ million of derivative loss (Pfizer Inc.) to $\$ 3,497$ million of derivative gains (Apple). We discuss both reclassifications below.

During the year ended September 26, 2015, Apple recognized a $\$ 3,497$ million gain on all its hedges (net of tax expense of \$630). This was the total amount reclassified out of AOCI and the reclassification led to a $6.55 \%$ increase in net income. While the impact of this reclassification is positive, it illustrates that all derivative contracts eventually expire and need to be replaced. Apple's foreign exchange derivative contracts are typically in place for a period of 12 months and two thirds of company's revenue is generated abroad. (Note 9) So, the amount of hedged currency exposure will remain to be material in the future. In 2014 


\section{Macrothink}

International Journal of Accounting and Financial Reporting

ISSN 2162-3082

2018, Vol. 8, No. 2

Pfizer Inc. reclassified $\$ 477$ million of net realized losses on cash flow hedges from AOCI to the income statement. The amount is comprised of a $\$ 332$ million gain on foreign currency forward-exchange contracts and an $\$ 808$ million loss on foreign currency swaps. The reclassification led to $5 \%$ drop in net income.

Since every hedging contract is different, the impact of reclassified gains/(losses) on net income would be transaction-specific and therefore hard to predict. The timing of reclassification would likely depend on the timing of the hedged transaction (as opposed to management's willingness to report more gains and delay recognition of losses). Due to the transitory and highly volatile nature of derivative re-measurements reported in OCI, investors may not pay sufficient attention to this line item. However, the above examples show that reclassifications can be material, so unrealized gains/(losses) on derivatives are important and relevant for investment analysis. The OCI statement may alert investors that a company is facing significant foreign exchange headwinds or interest rate risks and reveal how big of an impact these risks may have on future earnings.

\subsection{Presentation of OCI Gains (Losses) in the Financial Statements}

Given the prevalence of losses for certain OCI items, we review the presentation format used by companies to report other comprehensive income to see if companies opt to "hide" unrealized losses in separate disclosures. Indeed, components of comprehensive income are most frequently reported as two separate consecutive statements with net income reported in the income statement and items comprising OCI reported in a separate statement of other comprehensive income. In our sample, $98 \%$ companies choose this presentation method over presenting OCI in a more prominent way, as a single continuous statement with the income statement. Exelon Corporation and Simon Property Group are the only two companies from our sample that report both components in a single "consolidated statement of operations and comprehensive income". It is expected that the form of presentation affects the way readers view and use OCI information. So, presenting OCI in a separate disclosure may be a means of diverting investors' attention from the potential risks and unrealized losses in OCI.

\section{Conclusion}

In this study, we examine the annual report filings of the S\&P 100 companies that report other comprehensive income/(loss) over the three-year period of 2013-2015. Our objectives are to gain a deeper understanding of the components of other comprehensive income and to determine if there is a systematic tendency for companies to include more gains or losses in other comprehensive income. Further, we seek to determine which components of other comprehensive income show more unexpected losses than gains and what impact other comprehensive income or losses may have on future earnings.

Our study findings show a tendency for our sample firms to include losses in OCI. We find that while in 2013 our sample companies were rather evenly split on reporting overall other comprehensive income or loss, in 2014 and 2015, 81\% and 85\%, respectively, of our sample companies report an overall other comprehensive loss, where other comprehensive losses exceed other comprehensive gains. Further, the losses reported in OCI are on average greater 
than reported OCI gains. Overall, our findings affirm that there is a tendency for companies to report losses in OCI both more frequently and in greater amounts than gains.

In examining the impact of different OCI components on net income we find that total other comprehensive loss is mostly driven by negative foreign currency translation adjustments and by unrealized losses on available-for-sale investments. The prevalence of investment losses is of particular note given the discretionary nature of the timing of the recognition in net income of these losses. In 2013 and 2015, respectively, 59\% and 75\% of sample companies reported more investment losses than gains in OCI. The mean value of unrealized investment losses is found to be greater than the mean value of gains. While our data do not speak to the motives of these decisions, it affirms a general tendency of companies to delay recognition of investment losses by keeping them in OCI. By leaving material investment losses "on paper" companies can paint their performance in a more positive light.

The review of translation re-measurements also shows a prevalence of losses included in OCI of between $71 \%$ and $93 \%$ of sample firms during the years 2013 through 2015 . The amount of mean foreign currency losses exceeds the amount of mean foreign currency gains for each reporting period. Given the strengthening of the U.S. dollar, the prevalence of translation losses is mostly driven by exchange rate movements as opposed to managers' preference to keep losses in OCI. However, it is still possible for companies to delay recognition of foreign currency losses, for example, by postponing divestment of a foreign subsidiary. Multiple reclassifications of foreign currency losses show that these OCI items do eventually flow through net income. The study findings confirm that OCI information is economically meaningful for both investors and CFOs, as it highlights the risks and the need for additional planning to minimize the impact of future reclassifications on earnings.

In the study we also examine pension-related gains and losses and derivative-related gains and losses included in OCI. Pension-related gains included in OCI exceed losses in 2013 and 2015. As to derivatives-related gains and losses included in OCI, gains exceed losses in 2014, while losses exceed gains in 2015. Gains and losses included in OCI are evenly split in 2013.

Several newspaper articles and academic research publications suggest that investors are not incentivized to pay much attention to OCI information. They tend to overlook the statement of other comprehensive income, thinking that it simply aggregates volatile and transitory fair value re-measurements and/or includes unrealized gains/(losses) that are less relevant to performance analysis. We hope to change that perception. Our findings show that 43 companies of the S\&P 100 reclassified accumulated gains and losses from AOCI to net income over the period of 2013-2015. Derivative gains/(losses) were transferred to earnings most frequently (89 reclassifications), followed by the reclassification of realized investment gains/(losses) (77 reclassifications) and pension-related reclassifications (36). When these OCI gains/(losses) became realized and were recorded in net income, they often had a material impact on earnings. Hence, our study shows both the significance of OCI components in relation to net income, and the transfer of accumulated material losses from AOCI to the income statement. This affirms that OCI information is relevant: it can enhance performance analysis and help investors anticipate the potential impact of such 
reclassifications on earnings. We hope to encourage all users of financial statements to increase scrutiny and incorporate different OCI components in their analysis.

Our findings highlight that the income statement alone does not tell the whole story of company's performance and how various economic events affected the business. The statement of other comprehensive income provides loopholes that companies can exploit to hide significant risk exposures and losses that can be damaging to earnings. Analysts and investors should make efforts to review OCI information, as it is a precursor of future net income. Accumulated unrealized gains/(losses) are often material, so ignoring them is dangerous and can leave the users of financial statements blindsided by the ultimate income statement effects of these items. Beyond users of financial statements, regulators, such as the FASB and SEC may want to reconsider whether items of OCI should be included in net income.

The current study does have limitations that affect the generalizability of its results. As with all archival research, especially research that entails the labor-intensive examination of financial statements and footnotes, the sample is limited to the 100 large companies comprising the S\&P 100 index for a three-year period. A larger, more diverse sample would strengthen the statistical tests employed. Further, new insights could be gained by examining results for other years across differing market environments. Finally, an experimental design that looks at whether informed subjects tend to de-emphasize results reported in OCI could provide an effective, alternative means of extending the research.

\section{Acknowledgement}

The authors appreciate the helpful comments of readers of the research circulated by the Georgia Tech Financial Analysis Lab. An earlier version of this paper was circulated by the Lab as an unpublished working paper.

\section{References}

Chasan, E. (2014). Accounting 'Dumping Ground' Headed for Clean Up. The Wall Street Journal, February 13, 2014. Retrieved from https://blogs.wsj.com/cfo/2014/02/13/accounting-dumping-ground-headed-for-clean-up/

Doron, N. (2011). Relative Valuation of U.S. Insurance Companies. New York: Columbia Business School. Retrieved from http://www.columbia.edu/ dn75/Relative\%20Valuation\%20of\%20U.S.\%20Insurance\%20Co mpanies.pdf

Financial Accounting Standards Board. (1997). Accounting Standards Codification 220: Reporting Comprehensive Income. Norwalk, Connecticut: Financial Accounting Standards Board.

Hoogervorst, H. (2014). The Dangers of Ignoring Unrealized Income. Tokyo: Speech delivered to the International Financial Reporting Standards Conference, September 3, 2014. Retrieved

from 


\section{Macrothink}

International Journal of Accounting and Financial Reporting ISSN 2162-3082

http://www.ifrs.org/Alerts/Conference/Documents/2014/Speech-Hans-Hoogervorst-Dangersof-ignoring-unrealised-income-September-2014.pdf

Ibid. (2010). Accounting Standards Codification 815: Derivatives and Hedging. Norwalk, Connecticut: Financial Accounting Standards Board.

Ibid. (2016). Accounting Standards Codification Update 2016-01 to ASC 825: Financial Instruments, Recognition and Measurement of Financial Assets and Financial Liabilities. Norwalk, Connecticut: Financial Accounting Standards Board.

Kieso, D., Weygandt, J., \& Warfield, T. (2016). Intermediate Accounting (16 ${ }^{\text {th }}$ ed.), pp. XX-XX). New York: John Wiley \& Sons.

Levine, M. (2014). Banks Prefer Losses They Don't Have to Talk about. Bloomberg, February 26, 2014. Retrieved from https://www.bloomberg.com/view/articles/2014-02-26/banks-prefer-losses-they-don-t-have-t o-talk-about

Niu, E. (2016). Apple, Inc.'s Foreign Exchange Risk Isn't Going Away Anytime Soon. The Motley Fool, January 22, 2016. Retrieved from https://www.fool.com/investing/general/2016/01/22/apple-incs-foreign-exchange-risk-isnt-go ing-away-a.aspx

Papa, V., \& Peters, S. (2015). Analyzing Bank Performance: Role of Comprehensive Income. New York: CFA Institute. Retrieved from http://www.cfapubs.org/doi/pdf/10.2469/ccb.v2015.n3.1 


\section{Appendix}

Exhibit 1. Outliers excluded from calculating summary statistics on OCI gains and losses

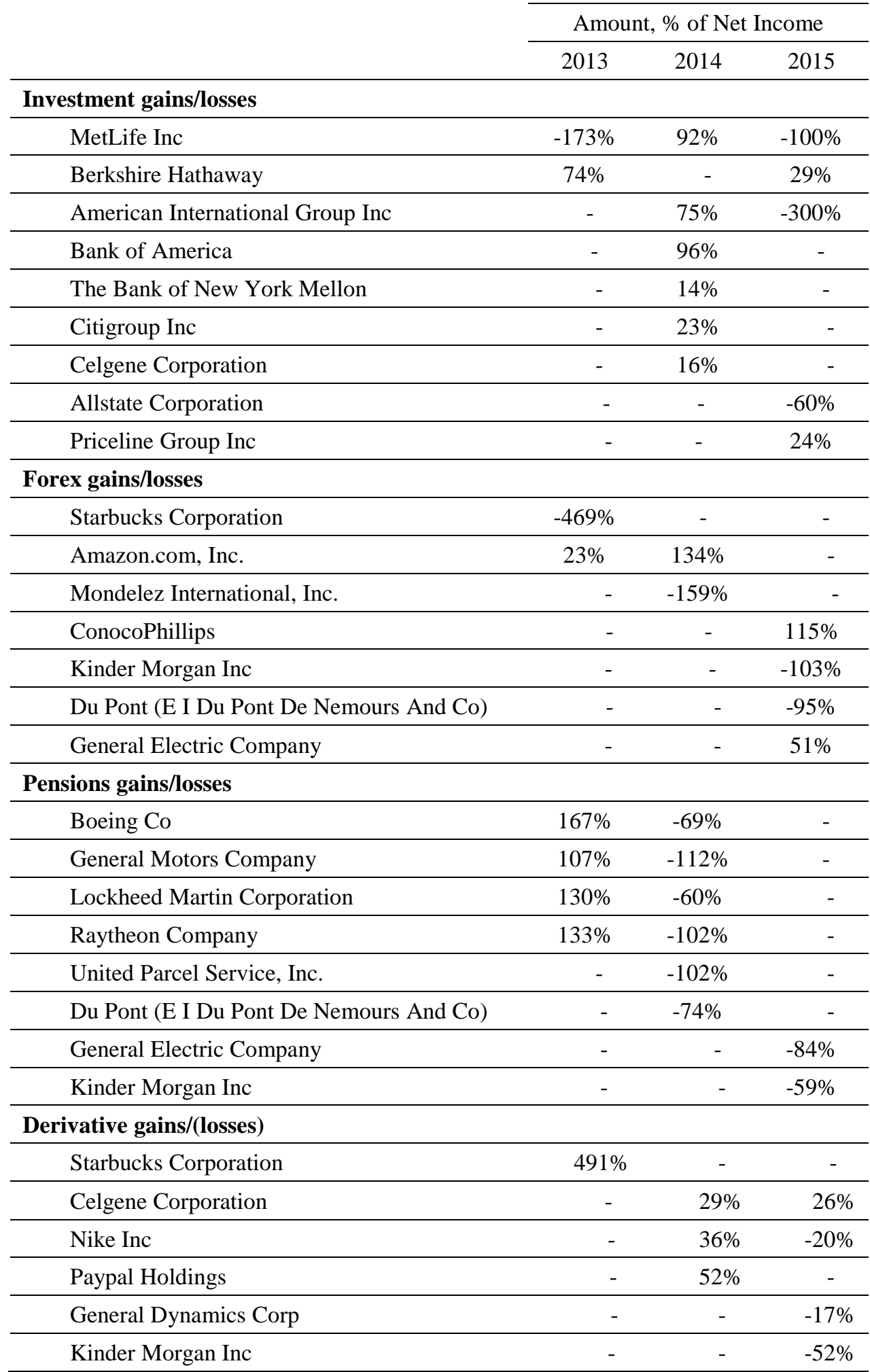




\section{Macrothink \\ International Journal of Accounting and Financial Reporting \\ ISSN 2162-3082 \\ 2018, Vol. 8, No. 2}

\section{Notes}

Note 1. While many analysts would adjust net income for nonrecurring gains and losses to derive a measure of non-GAAP income, still the primary focus as a starting point is net income and not comprehensive income.

Note 2. As a result of ASC Update 2016-01, (FASB 2016), effective for fiscal years beginning in 2018, gains/(losses) on available-for-sale equity investments will be recorded in net income. Such gains/(losses) on debt investments will continue to be recorded in other comprehensive income.

Note 3. ASC 815 (FASB 2010) defines cash flow hedges as hedges of the variable cash flows associated with assets,

liabilities, or transactions. It defines recognition criteria for cash flow hedge, as follows:

1) anticipated or forecasted transaction has variable cash flows,

2) transaction is probable of occurring in the future (there is no requirement for contractual commitment),

3) amount of the transaction has not been fixed.

For cash flow hedges, the effective portion of the gains and losses are recognized in other comprehensive income, while the ineffective portion of the gains and losses are recognized in earnings.

Note 4. Individual company results are available from the authors.

Note 5. As measured by the US Dollar Index (DXY) over 2013-2015.

Note 6. DXY closed at 80.5, 80.79, 91.08, 98.63 in 2012, 2013, 2014, 2015, respectively.

Note 7. As measured by the S\&P500 index over 2013-2015.

Note 8. As measured by the U.S. FOMC's target federal funds rate.

Note 9. Refer to Niu (2016).

\section{Copyright Disclaimer}

Copyright for this article is retained by the author(s), with first publication rights granted to the journal.

This is an open-access article distributed under the terms and conditions of the Creative Commons Attribution license (http://creativecommons.org/licenses/by/4.0/) 